\title{
Ege Üniversitesi Hastanesinde renal kanser hastalarının epidemiyolojisi ve genel sağ kalım özellikleri
}

\section{Epidemiological and overall survival characteristics of kidney cancer patients in Ege University Hospital database}

\author{
Pınar Gürsoy ${ }^{1}$ Burcu Çakar ${ }^{1}$ (D) Erhan Gökmen ${ }^{1}$ (i) Banu Sarsık Kumbaracı ${ }^{2}$ (D) Sait Şen ${ }^{2}$ \\ Erdal Apaydın ${ }^{3}$ A. Çağ Çal ${ }^{3}$ (iD $\quad$ Ayşe Caner $^{4}$ (D) Serdar Özkök ${ }^{5}$ (D) Ayfer Haydaroğlu ${ }^{5}$ (iD \\ ${ }^{1}$ Ege Üniversitesi Tıp Fakültesi, Medikal Onkoloji Bilim Dalı, İzmir, Türkiye \\ ${ }^{2}$ Ege Üniversitesi Tıp Fakültesi, Patoloji Bilim Dalı, İzmir, Türkiye \\ ${ }^{3}$ Ege Üniversitesi Tıp Fakültesi, Üroloji Bilim Dalı, İzmir, Türkiye \\ ${ }^{4}$ Ege Üniversitesi Tıp Fakültesi, Kanserle Savaş Araştırma ve Uygulama Merkezi, İzmir, Türkiye \\ ${ }^{5}$ Ege Üniversitesi Tıp Fakültesi, Radyasyon Onkolojisi Anabilim Dalı, İzmir, Türkiye
}

Öz

Amaç: Ege Üniversitesi Hastanesinde 1992-Haziran 2018 arası kanser tanısı konan ve tedavisi yapılan renal kanser tanılı hastaların genel özellikleri, tedavi modaliteleri ve sağ kalım sürelerinin tanımlanması amaçlanmıştır.

Gereç ve Yöntem: Ege Üniversitesi Kanserle Savaş Araştırma ve Uygulama Merkezi tarafından toplanan renal kanser verileri CANREG özel bilgisayar programına kayıt edilmiş, DSÖ ve SEER sistemleri temelinde gruplanarak analizler yapılmıştır. İstatistik analizlerde Fisher's Exact Test,KaplanMeier sağ kalım analizleri uygulanmıştır. Sağ kalım analizinde Log Rank (Mantel-Cox), Breslow (Generalized Wilcoxon) ve Tarone-Ware istatistikleri kullanılmıştır. İstatistik analizlerde $p<0,05$ istatistiksel olarak anlamlı kabul edilmiştir.

Bulgular: Çalışmada 1397'si $(\% 64,0)$ erkek ve 783'si $(\% 35,9)$ kadın toplam 2180 renal kanser hastasının verileri analiz edildi. Hastaların yaş ortalaması 65 idi. Tümörlerin \%91,9'u renal parankimden, \%8,07'si renal pelvisten köken almıştı. Parankim tümörlerinin yaklaşık \%85'ini renal hücreli karsinom (RCC) oluşturmaktadır. En sık görülen histolojik alt tip berrak hücreli karsinom olup, bunu nefroblastoma ve papiller karsinom izlemekteydi. Histolojik alt tipler arasında en iyi beş yıllık sağ kalım kromofob ve nefroblastomada idi. Berrak hücreli RCC ile diğer histolojik alt tipler arasında istatistiki fark yoktu. En kötü sağ kalım sarkom ve toplayıcı kanal tümörlerinde izlendi. Hastalar başvuru anında en sık evre $1(\% 46,6)$, sonra sırayla evre $4(\% 19,2)$, evre $2(\% 14,9)$, evre $3(\% 4)$ hastalık ile başvurmakta idi. Evre 1 hastalıkta beş yıllık sağ kalım \%88, evre 2'de \%65, evre 3'te \%27 ve metastatik hastalıkta \%17 idi. Hastaların \%89 da primer tümöre yönelik cerrahi yapıldığı görüldü, $\% 10,4$ hastada cerrahi uygulanmamıştı ve \%0,5'i ise bilinmemekte idi. Cerrahi yapılanlarda sağ kalım, yapılmayanlara göre anlamlı saptanmıştır.

Sonuç: Berrak hücreli karsinomlar en sık görülen alt tip olup çoğunlukla malign tümörlerdir. Kromofob ve nefroblastoma ise genellikle benign tümörler olup daha iyi sağ kalım ile ilişkilidirler. Kadın cinsiyet ve cerrahi tedavi uygulanması daha iyi sağ kalımla ilişkilidir.

Anahtar Kelimeler: Böbrek kanseri, epidemiyoloji, insidans, genel sağ kalım.

\section{Abstract}

Aim: The purpose of this study was to describe the general characteristics, treatment modalities and overall survival times of kidney cancer patients that diagnosed and treated in between 1992 -and June 2018 at Ege University Hospital.

\footnotetext{
Yazışma Adresi: Pınar Gürsoy

Ege Üniversitesi Tıp Fakültesi, Medikal Onkoloji Bilim Dalı,

İzmir, Türkiye

E-mail: pinargursoy77@gmail.com
} 
Materials and Methods: Ege University Cancer Control, Research and Application Center registered the collected kidney cancer data in CANREG which is a special computer program for grouping and analyzing the data in WHO and SEER based systems. Fisher's Exact Test Kaplan Meier survival analyzing technique was used in statistical analysis. Log Rank(Mantel-Cox), Breslow(Generalized Wilcoxon) and Tarone-Ware statistical techniques were used in survival analysis. $P<0,05$ was considered significant in statistical analysis.

Results: A total of 2180 kidney cancer patient (1397 male, 783 female) were included in the analysis. The mean age of the patients was 65 years.91.9\% of them originated from renal parenchyma and $8,07 \%$ of them originated from renal pelvis. Approximately $85 \%$ of parenchymal tumors constitute renal cell carcinoma (RCC). The most common histological subtype was clear cell carcinoma, followed by papillary carcinoma and Wilms tumor. Among the histological subtypes, the best 5-year survival was in chromophobe and Wilms tumor. There was no statistical difference between clear cell RCC and other histological subtypes. The worst survival was detected at sarcoma and collecting canal tumor patients. The most common presentation was stage 1 (46.6\%), followed by stage 4 (19.2\%), stage 2 (14.9\%), stage $3(4 \%)$ disease. Five-year survival was $88 \%, 65 \%, 27 \%$ and $10.4 \%$ in stage $1,2,3$ and metastatic patients respectively. We detected that $89 \%$ had undergone surgery for primary tumor, $10.4 \%$ had surgical intervention for their disease, and $0.5 \%$ was unknown. Survival was significantly higher in the surgical group than in the surgical group.

Conclusion: Clear cell carcinomas are the most common subtype and mostly malignant tumors. Chromophobe and Wilms tumors are usually benign tumors and are associated with better survival. Female sex and surgical treatment are associated with better survival.

Keywords: Kidney cancer, epidemiology, incidence, overall survival.

\section{Giriş}

Böbrek tümörleri tüm kanserlerin \%4,2'sini oluşturmaktadır. Ürolojik kanserler arasında prostat ve mesane kanserinden sonra üçüncü sıklıkta görülür. Tüm kanser ölümlerinin \%2,4 'sini içermektedir(1). Böbrek tümörlerinin \%90'ı parankimden,\%5-10'u ise kaliks ve pelvis renalisten kaynaklanır. Parankim tümörlerinin yaklaşık \%85'i renal hücreli karsinom (RCC)oluşturmaktadır RCC insidansı bölgeden bölgeye değişiklik göstermekle beraber en sık Çek Cumhuriyeti ve Kuzey Amerika'da rastlanmaktadır. Retroperitonda bulunan bir organ olması nedeniyle ancak ileri evrede semptomatik hale gelmektedir. Ülkemizde de ultrason, tomografi, magnetik rezonans gibi görüntüleme yöntemlerinde yaşanan gelişmeler ve tarama sıklığında artış olması nedeniyle, insidental tümör saptanma oranı 1970'li yıllarda \%10 iken, 2000'li yıllarda bu oran \%65'lere kadar yükselmiştir.

Böbrek tümörlerinin büyük bir kısmı epitelyal orijinli ve maligndir. Renal epitelyal tümörlerin sınıflaması son dekatlarda belirgin değişikliklere uğramıştır. Temel morfoloji, immünhistokimya, sitogenetik ve moleküler patolojideki gelişmeler farklı tümör tiplerini gündeme getirmiştir. Böbrek tümörlerinin yaklaşık \%85'i renal hücreli karsinom olup, bu grubunda \%70'ini berrak hücreli karsinom oluşturmaktadır. Son olarak, Dünya Sağlık Örgütü'nün (DSÖ) 2016 yılında yayınladığı ürogenital tümörlerin sınıflamasında belirgin revizyonlar mevcuttur. Böbrek tümör tipleri arasına herediter leiomyomatozis ve renal hücreli karsinom sendromu-ilişkili renal hücreli karsinom, süksinat dehidrogenaz eksikliği ilişkili RCC, tübülokistik RCC, edinsel kistik hastalık-ilişkili RCC ve berrak hücreli papiller RCC gibi yeni epitelyal tümör tipleri dahil edilmiştir (2).

Ürotelyal karsinomalar ise renal pelvisten köken alır ve daha nadir görülürler. Ürotelyal kanserlerin yaklaşık \%4'ü böbrekte gelişir. Sarkomlar, nefroblastoma, lenfoma, lösemi ve renal metastazlarda böbreğin malign tümörleridir. Böbreğe en sık metastaz yapan kanser akciğer kanseri olup genelde bilateral ve multiple olma eğilimindedirler.

RCC kadınlara kıyasla erkeklerde \%50 daha sık görülmektedir. 2009-2015 Surveillance Epidemiology and End Results (SEER) verilerine göre 6 . ve 7 . dekatta ortalama 64 yaş civarında 
sıklığı artmakta olup, 40 yaş altı ve çocuklarda nadirdir. Ortalama ölüm yaşı 71'dir (1).

Bugüne kadar RCC etyolojisinde birçok faktör suçlanmıştır. Sigara içimi, endüstriyel ürünlerdeki karsinojenik arseniğe direkt ya da içilen sular aracılığı ile maruz kalmak RCC riskini \%30 arttırmaktadır. Çok sayıdaki retrospektif ve prospektif epidemiyolojik çalışmalarda artmış vücut kitle indeksinin böbrek kanseri riskini arttırdığı gösterilmiştir. Obezite ve sigara içiminden bağımsız olarak hipertansiyon öyküsü de RCC insidansını arttırmaktadır. Sigara günümüzde RCC gelişiminde suçlanan en önemli faktör olup dahası daha ileri evre hastalık ile ilişkili gibi görünmektedir. RCC çoğunlukla sporadik olarak saptanmakla beraber \%2-3 oranında herediter RCC'ye rastlanabilmektedir. Von Hippel Lindau $(\mathrm{VHL})$ hastalığı en sık görülen herediter renal kanser sendromudur.

Böbrek kanserini düşündüren belirti ve bulgular olduğunda ilk yapılması gereken renal ultrasonografi (USG) veya bilgisayarlı tomografidir (BT). Magnetik rezonans (MR) ise USG veya BT ile karakterize edilemeyen lezyonlarda, radyokontrast verilemeyen hastalarda ve damar tutulumunu göstermede yararlıdır (3-5). Daha önceleri $3 \mathrm{~cm}$ 'nin altındaki böbrek kitlelerinin benign adenom oldukları düşünülmekteydi. Ancak çok küçük tümörler bile metastaz yapabilmektedirler. Bu nedenle solid böbrek kitlelerinde histolojik tanı konulması önerilmektedir. RHK tanısı nadir olarak böbrek biyopsisi ile konulmaktadır. Histolojik tanı çoğunlukla görüntüleme testlerinden sonra yapılan nefrektomi ile konulmaktadır. Pozitron emisyon tomografisi (PET) renal hücreli kanserin tanı ve takibinde rutin kullanımı sınırlıdır (6).

Renal tümörleri derecelendirmek için çok sayıda derecelendirme sistemi tanımlanmıştır. Bunlar arasında Fuhrman ve ark.'nın önerdiği sistem öne çıkmış ve yaygın olarak kullanılmıştır. Bu sistem, tümörleri nükleer boyut, nükleer membran düzensizliği ve nükleol belirginliğini değerlendirerek derecelendirmektedir (7). Ancak bu sık kullanılan derecelendirme sistemi de subjektif olup sorunlar içermektedir. Bu nedenle DSÖ tarafından daha sade olan DSÖ / ISUP (International Society of Urological Pathology) derecelendirme sistemi önerilmiştir (Tablo-1).
Tablo-1. DSÖ / ISUP (International Society of Urological Pathology) derecelendirilmesi.

Grade 1 Nükleol yok ya da belirsiz ve 400x büyütmede bazofiliktir.

Grade 2 Nükleol belirgin ve 400x büyütmede eozinofiliktir, 100x büyütmede belirgin değil ancak görülebilir.

Grade 3 Nükleol 100x büyütmede belirgin ve eozinofiliktir

Grade 4 Belirgin nükleer pleomorfizm, multinükleer dev hücreler ve / veya sarkomatoid ve / veya rhabdoid diferansiyasyon

SEER verilerine göre 2006-2015 yılları boyunca her yıl ortalama görülme sıklığı $\% 0,6$, ölüm hızı ise $\% 0,7$ oranında artmaktadır. Beş yıllık sağ kalımda lokalize hastalıkta \%88,4 den \%92,5'ya, ileri evre hastalıkta $\% 7,3$ den $\% 12$ ye artmaktadır. RCC'de en önemli prognostik faktörler tümörün evresi, lenf nodu varlığı, grade, tümörün yaygınlık derecesidir. En sık akciğer, kemik, karaciğer, lenf nodları, adrenal bez ve beyine metastaz yapmaktadır.

Erken evre ve lokal ileri evre hastalıkta ilk tedavi radikal nefrektomi olup adjuvan tedavinin genel sağ kalım verisi henüz net olmadığından günümüzde her hastaya önerilmemektedir. Metastatik hastalıkta ise özellikle oligometastatik hastalıkta sitoredüktif cerrahi ve metastazektomi düşünülebilir. Evre 4 hastalıkta hastalar Memorial Sloan Kettering Cancer Center (MSKCC) ya da International Metastatic Renal Cell Carsinom Database Consortium (IMDC) gibi prognostik kriterlerle gruplara ayrılarak tedavi seçenekleri belirlenir. lyi risk gruplarında tirozin kinaz inhibitörleri tercih edilirken, orta ve yüksek risk hastalarda özellikle immunoterapi önerilmektedir.

Biz çalışmamızda Ege Üniversitesi Hastanesi (EÜH)'de 1992-Haziran 2018 arası kanser tanı ve tedavisi yapılan 2180 renal kanser hastasının epidemiyolojik ve genel sağ kalım özelliklerini tanımlamayı amaçladık.

\section{Gereç ve Yöntem}

Ege Üniversitesi Kanserle Savaş Araştırma ve Uygulama Merkezi tarafından toplanan renal kanser verileri CANREG özel bilgisayar programına kaydedilmiş, DSÖ ve SEER sistemleri temelinde gruplanarak analizler yapılmıştır. İstatistik analizlerde Fisher's Exact Test, Kaplan-Meier sağ kalım analizleri uygulanmıştır. Sağ kalım analizinde Log Rank (Mantel-Cox), Breslow (Generalized Wilcoxon) ve Tarone-Ware istatistikleri kullanılmıştır. İstatistik 
analizlerde $p<0,05$ istatistiksel olarak anlamlı kabul edilmiştir. Olguların büyük çoğunluğu üroloji anabilim dalında ameliyat edilen, tedavileri hastanemizde yapılan olgular olup, dış hastanelerde tanı alıp tedavi için başvuran olgular da bulunmaktadır. Çalışmanın etik kurul onayı 19.10T / 60 numarası ile Ege Üniversitesi etik kurulundan alınmıştır.

\section{Bulgular}

EÜH veri sisteminde kayıtlı 2180 böbrek tümörü hastasının en sık görüldüğü yaş $60-70$ yaş aralığındadır (Şekil-1). En sık görülen histolojik alt tip olan berrak hücreli karsinom görülme yaşı 61-70 iken (Şekil-2), özellikle değişici epitel karsinomlarına daha geç yaşlarda (71-80) rastlanmıştır (Şekil-3).

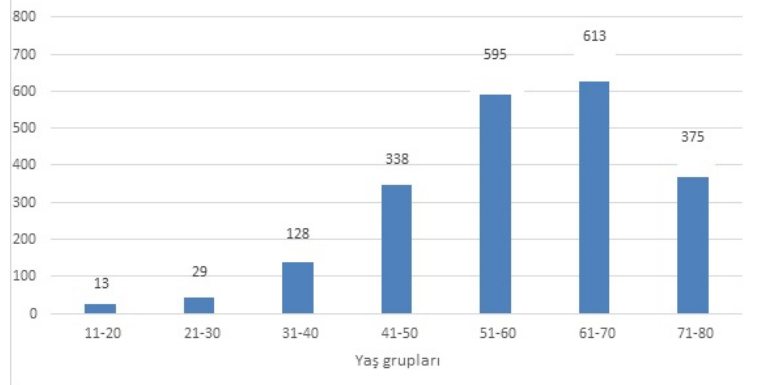

Şekil-1.Renal tümörlerin yaşlara göre dağılımı.

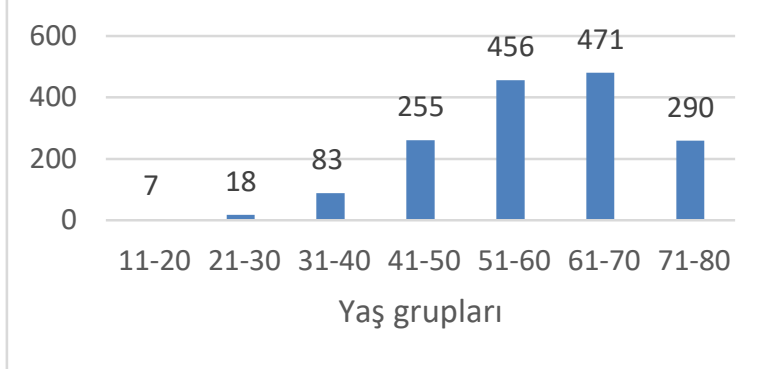

Şekil 2. Berrak hücreli kanserin yaşlara göre dağııımı.

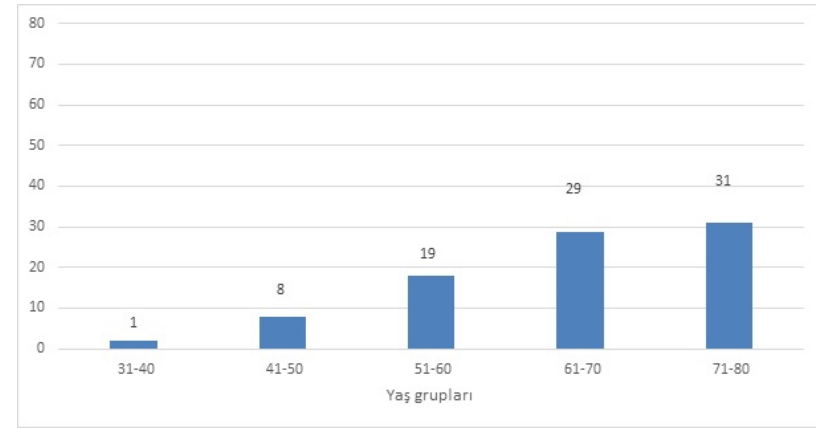

Şekil-3. Ürotelyal karsinom yaş gruplarına göre dağılımı.

Hastalarımızın 1397'si $(\% 64,0)$ erkek, 783'si $(\% 35,9)$ kadın idi. Böbrek tümörlerinin \%91,9'u renal parankimden, \%8,07'si ise renal pelvisten köken almıştı. Renal pelvisten köken alan tümörlerin $\% 43,1^{\prime}$ ini ürotelyal karsinom oluşturmuş olup nadiren lenfoma $(\% 1,1)$ ve nöroendokrin tümör $(\% 0,56)$ tutulumları da gözlenmiştir. Böbrek parankimden köken alan tümörler arasında ise sık görülen histolojik berrak hücreli karsinom alt tipi olup \%72,5'ini oluşturmaktadır. Diğer görülen alt tiplerin sıklığı sırayla nefroblastoma \%6,6, papiller \%6,5, kromofob \%5,6 ve toplayıcı kanal tümörleri $\% 0,45$ idi. Diğer alt tipler için tutulum oranları Tablo-2 de verilmiştir. Renal kanser insidansı 2014 yılına kadar artmış olup 2014 yılından sonra stabil kalmıştır (Şekil-4).

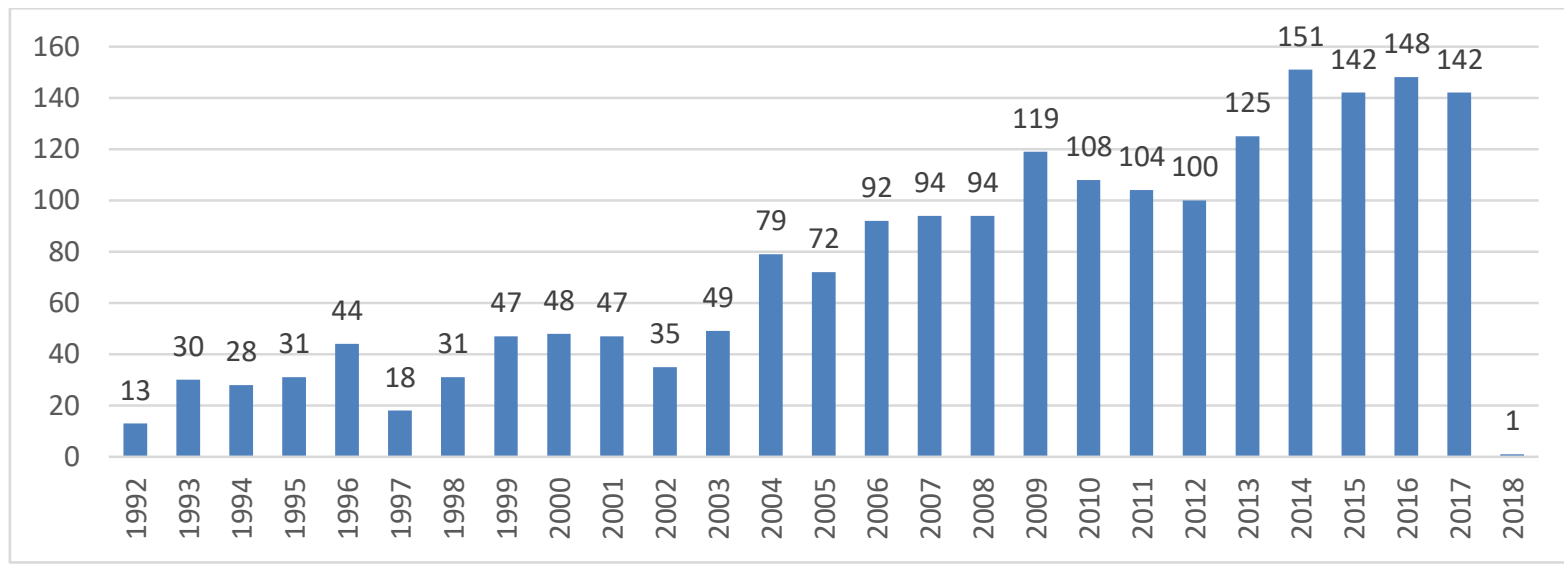

Şekil-4. Böbrek tümörlerinin yıllara göre dağılımı. 
Histolojik alt tipler arasında en iyi beş yıllık sağ kalım kromofob tümörde \%93, nefroblastoma $\% 79$, papiller RCC $\% 74$ idi. Berrak hücreli RCC de ise 5 yıllık sağ kalım \%63 olup, alt tipler arasında istatistiki fark yoktu(p:0,00). En kötü sağ kalım ise sarkom (\%33) ve toplayıcı kanal tümörlere (\%16) aitti (Şekil-5).

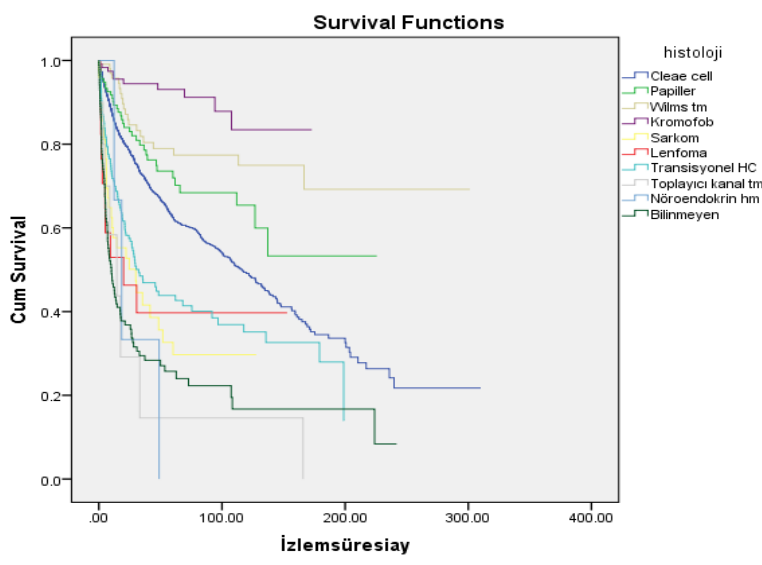

Şekil 5. Histolojik alt tipler göre sağ kalım.

Hastaların \%3,6'sında iyi diferansiye (grade 1), $\% 23,3$ 'ünde orta diferansiye (grade 2), \%20,0'ünde kötü diferansiye (grade 3) ve $\% 8,85$ 'inde anaplastik diferansiyasyon (grade 4) saptanmıs olup \%43,3 hastanın ise diferansiyasyon durumu bilinmemekteydi. Her ne kadar diferansiyasyonu belli olmayan hastalar fazla olsada diğer gradelerdeki sağ kalımlar Şekil-6'da verilmiştir.

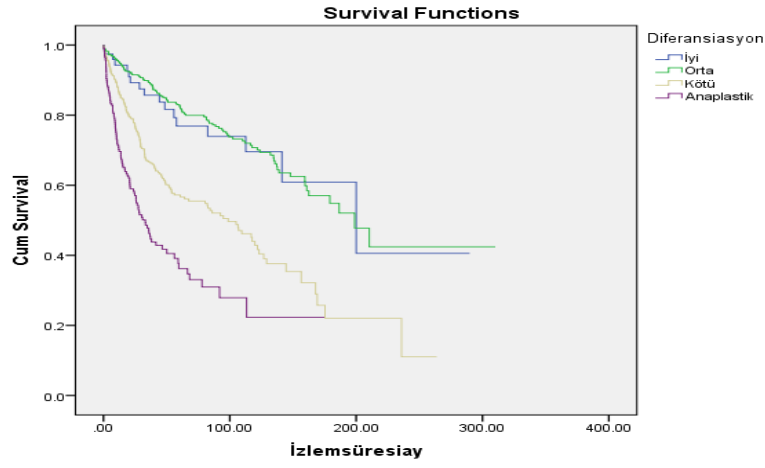

Şekil-6. Diferansiyasyon ile sağ kalım ilişkisi.

Hastaların başvuru anındaki evrelerine bakıldığında en sık \%46,6 evre 1 hastalık ile yani lokalize hastalık ile başvurmaktadırlar. Daha sonra sırasıyla evre $4(\% 19,2)$, evre $2(\% 14,9)$, evre $3(\% 4,0)$ idi. \%15,0 hastanın ise evresi bilinmemekteydi. Evre 1 hastalıkta beş yıllık sağ kalım \%88, evre 2'de \%65, evre 3'te \%27 ve metastatik hastalıkta \%17 (Şekil-7) idi.

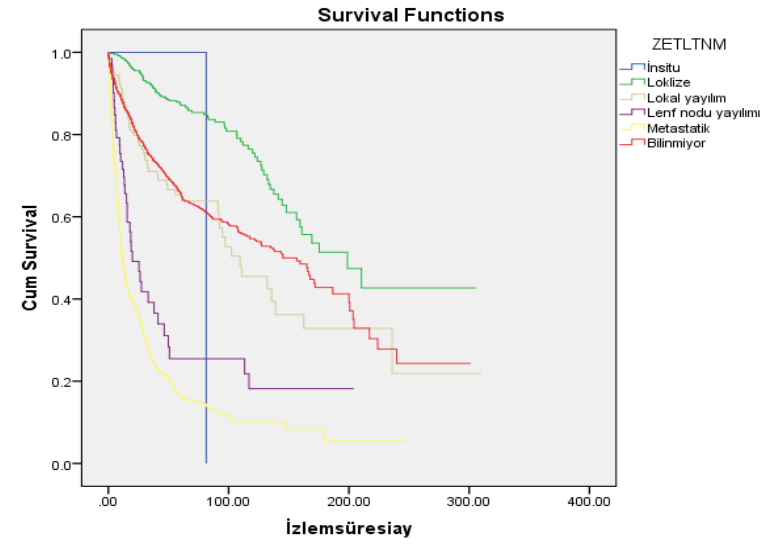

Şekil-7. Evrelere göre sağ kalım.

Böbrek tümörleri lokal hastalık durumunda saptandığında cerrahi eksizyon ile kür şansı olmaktadır. Hatta metastatik hatta da bazı hasta gruplarında cerrahinin faydalı olduğu bilinmektedir. Bizim olgularımızda da hastaların 1942'si (\%89) cerrahi yapılmış, 227'si $(\% 10,4)$ cerrahi yapılmamış ve $11^{\prime} \mathrm{i}(\% 0,5)$ ise bilinmemekte idi. Cerrahi yapılanların \%71,7'si erken evre ve lokal ileri evrede, \%14,4'ü ise metastatik evrede cerrahi uygulanmıştır.

Cerrahi yapılan hastaların sağ kalımları ortanca 144 ay olup, yapılmayan hastaların sağ kalımı ortanca 10,3 aydır. Hasta verilerinde 380 hastanın cerrahi sonrasında herhangi bir tedavi aldığı belirtilmiş ancak aldıkları tedavilere ilişkin veriye ulaşılamamıştır. Cerrahi sonrası tedavi olmayan hastaların sağ kalımı 129 ay iken, tedavi olan hastaların 34 ay idi. Bunun sebebinin tedavi olmayan hastaların erken evrede olmaları ve tedavi alan hastaların ise çoğunlukla metastatik evrede olmaları olabilir.

Hastaların genel sağ kalım özelliklerine bakıldığında kadın hastaların genel sağ kalımı 148 ay ve erkeklerin sağ kalımı 101 ay olup bu iki grup arasında istatistiksel fark mevcuttur $(p<0,001)$.

Hastalarımızın 1397'si (\%64) halen yaşamakta, 783 'ü $(\% 35,9)$ ise kaybedilmiştir. Sağ kalımlara bakıldığında 5 yıllık sağ kalım oranı \%60,6, 10 yıllık sağ kalım \%49,2 ve 15 yıllık sağ kalım \%36,7 idi.

\section{Tartışma}

RCC Amerika Birleşik Devletlerinde yaklaşık 74,000 yeni vaka ve 15,000 ölüme, Avrupa'da ise yaklaşık 84,000 yeni vaka ve 35,000 ölüme neden olmaktadır. Bizim verilerimizde özellikle 2006 
yılında ve 2014 yılında sıklığı artmış olup son yıllarda insidans stabil kalmıştır. Literatürlerde de dünya genelinde son yıllarda böbrek tümörleri için insidansta artış belirgin değildir.

Hastalığın görülme yaşı ve erkek cinsiyet hâkimiyeti literatürle aynı olup özellikle ürotelyal karsinomların daha ileri yaşlarda görüldüğü dikkati çekmektedir.

2016 yılında DSÖ tarafından yeni patolojik sınıflama yapılmış olsa da revizyon yapılan histolojik alt tiplere sık rastlanmaması nedeniyle insidansta farklılıklara neden olmamıştır. Bizim serimizde $\% 0,73$ berrak hücreli papiller RCC ve $\% 0,09$ edinsel kistik hastalık-ilişkili RCC nadir görülen bu alt tipleri oluşturmaktadır. Diğer histolojik alt tiplerin sıklığı bizim olgularımızda da literatürle aynıdır (Tablo-2).

Tablo-2.Histolojik alt tiplerin sıklığı

\begin{tabular}{lll}
\hline Histoloji & Sayı & Yüzde \\
Berrak hücreli RCC & 1582 & 72.5 \\
Papiller karsinom & 143 & 6,5 \\
Kromofob & 123 & 5,6 \\
Nefroblastoma & 144 & 6,6 \\
Toplayıcı kanal tm & 10 & 0,45 \\
Kiste eşlik eden & 2 & 0,09 \\
Mixt tip & 16 & 0,73 \\
Sarkom & 52 & 2,3 \\
Ürotelyal karsinom & 89 & 4,08 \\
Nöroendokrin tm & 3 & 0,13 \\
\hline
\end{tabular}

Tümör gradeleri histolojik tipten bağımsız olarak prognozu etkilemektedir. Yapılan bir çalışmada beş yıllık sağ kalım grade 1'de \%89, grade 2'de $\% 65$ ve grade $3-4$ 'te $\% 46$ bulunmuştur. Bizim verimizde de grade 1 ve grade 2 arasındaki sağ kalım grade 3-4 diferansiyasyona göre daha iyidir.

Böbrek tümörlerinde histolojik alt tipler ile sağ kalım değişmektedir. Nefrektomi yapılmış 2400 sporadik böbrek kanserinin incelendiği bir çalışmada beş yıllık sağ kalım berrak hücreli RCC'DE \%68,9,papiller tipte \%87,4 bulunmuştur (8).Toplayıcı kanal tümörleri daha çok genç bireylerde gelişmektedir ve oldukça agresiftir. M.D. Anderson merkezinden bildirilen bir çalışmada metastatik 606 hastanın verileri retrospektif olarak incelenmiş, berrak hücreli dışındaki renal hücreli kanser hastalarının sağ kalımı 9,7 ay iken berrak hücrelilerinki 20,3 ay bulunmuştur (9). Sarkomatoid diferansiasyon tüm histolojik subtiplerde gelişebilmektedir ve prognozu belirgin olarak kötüleştirmektedir. Bizim verile-rimizde de en iyi sağ kalım berrak hücreli ve papiller karsinomda olup, sarkomatoid karsinom ve toplayıcı kanal tümörleri en kötü sağ kalıma ait histolojik alt tipleri oluşturmaktadır.

SEER 2009-2015 verilerine göre evre 1 lokalize hastalık \%65, evre 2-3 lokal ileri hastalık \%16 ve evre 4 metastatik hastalık ise \%16 olarak bildirilmiş. $\mathrm{Bu}$ verilerde $\% 3$ hastada evrelendirilememiştir (1). Bizim verilerimizde \%15 hastanın evresinin bilinmediğini ve bu hastaların büyük çoğunluğunun cerrahi sonrası herhangi bir tedavi almadığını düşünürsek bu oranın büyük çoğunluğu non-metastatik hastalık olduğunu varsayabiliriz. $\mathrm{Bu}$ da nonmetastatik hasta oranlarımızın literatüre yakın olabileceğini göstermektedir.

Ülkemizde 2007 yılından önce interlökin ve interferon dışında metastatik RCC tedavisinde kullanılabilecek etkin ajan bulunmamaktaydı. Hedefe yönelik tedaviler 2007 yılından itibaren kullanılmaya başlanmıştır. Literatürde hedefe yönelik tedavilerin kullanılmadığı dönemdeki sağ kalımlar ile kullanılmaya başladıktan sonraki dönemdeki sağ kalımlar arasında belirgin farklıık saptanmıştır $(10,11) .2007$ öncesi tanı alan renal kanserler olgularının 5 yıllık genel sağ kalımları \%41 iken 2007 ve sonrası tanı alanların \%48 idi. Bizim serimizde 2007 öncesi ve sonrası sağ kalımlar aynı olup istatistiki fark saptanmamıştır $(p=0,130)$.

SEER verilerinde RCC hastalarının beş yıllık rölatif sağ kalımları lokalize hastalıkta \%92,5, bölgesel lenf nodu tulumunda \%69,6 ve metastatik hastalıkta ise \%12,0 olarak bulunmuştur, \%41,9 ise bilinmemektedir. Bütün gruplardaki sağ kalım ise beş yıllık \%74,8'dir. Bizim verimizde ise sağ kalımlara bakıldığında 5 yıllık sağ kalım oranı $\% 60,6,10$ yıllık sağ kalım \%49,2 ve 15 yıllık sağ kalım \%36,7 idi.

\section{Sonuç}

Böbrek tümörleri son yıllarda sıklığı sabit kalan ancak hedefe yönelik ajanların ve immunoterapi seçeneklerinin artmasıyla sağ kalımı daha iyiye giden bir kanserdir. En sık görülen alt tipi berrak hücreli karsinom olup, bunu papiller karsinom ve nefroblastoma izlemektedir. Berrak hücreli karsinomlar ile non-berrak hücreli karsinomlar arası sağ kalım aynı olup özellikle sarkomatoid diferansiye tümörler daha az sağ kalıma sahiptir. 
Hastalar her evrede cerrahi şansa sahip olup erken basamakta hastalarımızın çoğuna cerrahi yapılmıştır. Böbrek tümörlerinde sağ kalımı belirleyen klinik ve laboratuvar parametrelerin olduğu, risk gruplarının belirlendiği, alınan tedavilerin bilindiği daha geniş çalışmalar gerekmektedir.

\section{Kaynaklar}

1.SEER Stat Fact Sheets: Kidney and Renal Pelvis. http://seer.cancer.gov/statfacts/html/kidrp.html .

2.Störkel S,van den Berg E. Morphological classification of renal cancer. World J Urol. 1995;13(3):153-8.

3.Israel GM, Bosniak MA. How I do it: evaluating renal masses. Radiology, 236 (2), 441-50.

4.Johnson CD, Dunnick NR, Cohan RH, Illescas FF. Renal adenocarcinoma: CT staging of 100 tumors. AJR Am J Roentgenol, 148 (1), 59-63.

5.Koga S, Tsuda S, Nishikido M et al. The diagnostic value of bone scan in patients with renal cell carcinoma. J Urol, 166 (6), 2126-8.

6. Ramdave S, Thomas GW, Berlangieri SU et al.Clinical role of F-18 fluorodeoxyglucose positron emission tomography for detection and management of renal cell carcinoma. J Urol. 2001 Sep;166(3):825-30.

7.Novara G, Martignoni G, Artibani W, Ficarra V. Grading systems in renal cell carcinoma. J Urol. 2007 Feb;177(2):430-6.

8. Cheville JC, Lohse $\mathrm{CM}$, Zincke $\mathrm{H}$ et al. Comparisons of outcome and prognostic features among histologic subtypes of renal cell carcinoma. Am J Surg Pathol. 2003 May;27(5):612-24.

9. Kassouf W, Sanchez-Ortiz R, Tamboli $P$ et al. Cytoreductive nephrectomy for metastatic renal cell carcinoma with nonclear cell histology. . J Urol. 2007 Nov;178(5):1896-900. Epub 2007 Sep 17.

10. Motzer RJ, Hutson TE, Tomczak $P$ et al. Overall survival and updated results for sunitinib compared with interferon alfa in patients with metastatic renal cell carcinoma. J Clin Oncol. 2009 Aug 1;27(22):3584-90. doi: 10.1200/JCO.2008.20.1293. Epub 2009 Jun 1.

11.Rini BI, Halabi S, Rosenberg JE et al. Phase III trial of bevacizumab plus interferon alfa versus interferon alfa monotherapy in patients with metastatic renal cell carcinoma: final results of CALGB 90206. . J Clin Oncol. 2010 May 1;28(13):2137-43. doi: 10.1200/JCO.2009.26.5561. Epub 2010 Apr 5. 